\title{
The London Vagrancy Crisis of the 1780s
}

\author{
TIM HITCHCOCK \\ Department of History, \\ University of Hertfordshire, Hatfield, Hertfordshire, \\ $A L 109 A B, U K$
}

\begin{abstract}
This article outlines the changing character of vagrant removal from the City of London during the 1780s, suggesting that the City largely abandoned its duty to 'punish' the vagrant poor in favour of policy of simply moving them on as quickly and cheaply as possible. After describing the impact of the destruction of Newgate and the resulting overcrowding in London's other prisons, it provides evidence for a dramatic increase in vagrant numbers. The article suggests that this change was both a direct result of the crises of imprisonment, transportation and punishment that followed the Gordon Riots and American war; and a result of growing demand for the transportation provided to vagrants, on the part of the migratory poor. Having established the existence of a changing pattern of vagrant removal, it suggests that the poor increasingly made use of the City of London, and the system of removal, to access transportation in pursuit of seasonal migration, and more significantly, medical care in the hospitals of the capital as part of a wider 'economy of makeshift'.
\end{abstract}

About nine in the morning on the 30th March 1784, William Jenkins, apparently in good health, found himself surrounded by clean straw, sitting on a bench in the back of a 'commodious Covered Cart' as it trundled along Knightsbridge on its way to St Mary Le Bone, where Jenkins had a parish settlement.1 Jenkins was a 'vagrant' and was being 'removed' from Gloucester. During his journey he probably passed through the hands of three or four different 'vagrant contractors', each of whom was charged with conveying him and his fellows to the next jurisdiction. After perhaps a week's journey, he was on the final stage of his travels. The cart, driven by one William Yeates, belonged to Henry Adams, who was the vagrant contractor for the county of Middlesex, and had started out that morning from Stanwell Moor with Jenkins, Joseph Smith and 'several other paupers' in the back. Their first stop was Staines, 'where a Man his Wife and two Children were left' in the hands of a parish officer; and the other vagrants were given an opportunity to stretch their legs and have a late breakfast. Jenkins, 'drank three Penny worth of Purl and Eat a half Penny Roll', before climbing back in to the cart. As they proceeded, Jenkins grabbed the apron of one of his fellow vagrants, who complained that he was hurting her leg. He let go, and settled back on the bench only to be discovered dead, by the same woman, a few minutes later. 
We know a fair amount about William Jenkins' death, but we know very little about his life and experience as a vagrant. This article explores the changing system of vagrant removal as it evolved in the City of London and Middlesex through the 1780s and how it changed from a form of criminal prosecution characterised by whipping, hard labour and imprisonment, to a system that increasingly made medical care and transport available to the poorest of unsettled Britons.

Most historians of crime and poverty are familiar with the intertwined crises of punishment and criminal justice and of riot and social disorder, associated with the late 1770s and 1780s.3 The end of criminal transportation resulting from the outbreak of war in America in 1775 precipitated an unprecedented disruption in a well-established system of justice and punishment. Transportation to North America had been the mainstay of the courts for almost sixty years, since the passage of the 1718 Transportation Act, with hundreds of felons and vagrants exported each year. Denied this option, the criminal justice system was suddenly obliged to secure and care for an ever growing community of the disaffected and frankly criminal. The scale of the problem can be measured in simple numbers. Between 1766 and 1776, two-thirds of all sentences imposed at the Old Bailey, an average of 263 a year, included transportation. When transportation ended, convicts ended up in prisons that were ill-designed for long term incarceration, and simply did not have the space to accommodate them. 'The fact is', William Eden reported in March 1776, 'our prisons are full, and we have no way at present to dispose of the convicts'.4 In response, a hard pressed government created the system of 'Hulks', floating prisons in the form of retired merchant ships and in 1779 passed the Penitentiary Act, authorising the building of at least one national prison. 5 But the 'hulks' were a mere stopgap, while the Penitentiary Act was never implemented. This desperate situation became a real crisis following the Gordon Riots, which erupted on Friday 2nd June 1780. Within a week some 285 people (all rioters), were dead and 173 seriously injured. Some contemporary estimates put this number as high as 700.6 Over $£ 200,000$ of damage was inflicted on the fabric of the city, including the destruction of eighty-one private homes and businesses.7 The Gordon Riots were simply the most destructive example of civil unrest in post medieval British history. The important element of the riots for this article, however, was that the main objects of the rioters' ire were the prisons and lock ups of London, many of which were used to accommodate vagrants awaiting removal from the City and Middlesex. The rioters destroyed the City's central prison, Newgate, burning it to the ground, and releasing the prisoners. This was followed by assaults on the King's Bench and Fleet prisons. There were also attacks on New Prison and the house of correction at Clerkenwell in Middlesex. The 'cause', in the words of one rioter, Thomas Haycock, later hanged for his role in the destruction of Newgate Prison, was neither religion, nor the courts, but to ensure that 'there should not be a prison standing . . . in London'.8 One after another the prisons fell. As a result, by the end of the second week of June 1780 London's carceral fabric was in tatters, while its preferred mechanism for exporting the undesirable, transportation, would remain unavailable until 80 the dispatch of the 'First Fleet' to New South Wales almost seven years later in May 1787. This article is intended to point up how these developments forced the authorities of the City of London to reassess their treatment of the vagrant poor. It suggests that a crisis of vagrant removal in the 1780 s contributed to the creation of a new system for treating the unsettled and migratory poor and that both of these factors at 
least temporarily transformed the sort of person who found themselves labelled as a 'vagrant'. They also encouraged the migratory and sick poor to use the system to their advantage, normalising vagrancy as part of a wider migratory strategy.

On the face of it, by 1780 Britain was possessed of an organised and effective system of national vagrant removal that worked in parallel with the system of parish settlement to encompass all forms of non-elite migration. Between them, the settlement and vagrancy laws effectively identified the home parish of every individual in the country, based on a complex hierarchy of marriage, apprenticeship, and birth, and made legal provisions for the removal of paupers and vagrants from anywhere in the country, and for their conveyance back to their home parish. The system evolved through a combination of practice and legislation, but by the 1770s, when Thomas Gilbert spearheaded a parliamentary enquiry into the system, it had reached a moment of stasis. On the basis of returns collected for 1772, 1773, and 1774, Gilbert calculated that annual expenditure on poor relief for England and Wales ran to some $£ 1,720,316.7$ Provision for vagrant removal was less universal, with London and Middlesex, in combination with the England's other major cities, and the cross-road counties of the Midlands, shouldering the majority of the burden. But, Middlesex reported spending approximately $£ 150$ per annum on apprehending vagrants, around $£ 250$ per year on 'passing' them and a further $£ 600$ to $£ 800$ on imprisoning and punishing them. 8 The legal background governing this system was codified in Acts of Parliament passed in 1714 and 1744, and in theory at least, ensured that any constable willing to arrest a vagrant could collect a reward of two shillings, rising to five shillings, and even ten shillings for the prosecution of an 'incorrigible rogue', who could then be subjected to criminal transportation for seven years. The law also laid out periods of hard labour, with public whippings for all vagrants.9 For those lucky enough to be classified as the 'parish poor', settlement certificates and a growing body of case law, proved in the Court of King's Bench, governed their experience of migration and relief.10 In contrast, those defined as 'vagrants' faced an elaborate county run system of private prisons, combined with a justice of the peace administered system of punishment and removal.11 From 1700, when new legislation gave the county bench responsibility for funding vagrant removal, most counties and many incorporated cities subcontracted both the punishment, normally in the form of whipping and a period of hard labour, and removal of vagrants to prison turnkeys and independent 'vagrant contractors'. 12

In the county of Middlesex and the City of London, the system was made more complex by geography, since the City was almost entirely surrounded by Middlesex. In the administratively distinct jurisdiction of the City of London, vagrants were taken up by constables and watchmen, and normally brought before either the Lord Mayor or Court of Aldermen, and prior to the 1780s sentenced to hard labour and a whipping in Bridewell, the City's now ancient house of correction, before being removed to their home parish. In contrast, vagrants apprehended in Middlesex were normally examined by a Justice of the Peace sitting on his own in petty sessions, and committed to one or other of the counties' several houses of correction, before again being passed into the hands of Henry Adams, who was the county's 'vagrant contractor' for most of the last quarter of the eighteenth century. Because of the compact nature of the City of London it did not need a sophisticated system of vagrant removal of its own and could simply hand over the majority of its vagrants to Henry Adams to be passed to the counties beyond. Henry Adam's 
vagrant cart, with its doleful passengers secured in the back, could be seen trundling across the city on most days of the week, first northward and then southward. After collecting prisoners from both the City and Middlesex, 'the Bridewells four times, and others twice a week', Adams then delivered his passengers to one of his vagrant removal stations, prior to handing them over to the responsible contractor in the adjoining jurisdiction. 13

In practice, the implementation of these provisions was at best patchy. The legal definition of 'vagrancy' was woolly beyond understanding, and was made up of an apparently random list of under-specified categories of the undesirable.14 In both the 1714 and the 1744 Vagrancy Acts, the list of 'vagrants' included, among a host of equally absurd categories:

Patent gatherers ...

Collectors for prisons, gaols or hospitals ...

Fencers and bearwards...

Common players of interludes ...

All minstrels, jugglers ... .

All persons pretending to be Gypsies, or wandering in the habit or form of Egyptians... 15

Despite this definitional quagmire, there was a working system that at least superficially encompassed the migratory and disorderly poor. It criminalised a certain sub-class of the poor and allowed watchmen, parish constables or private citizens to arrest, punish and remove the undesirable. By the mid-1770s, Middlesex was committing an average of 531 vagrants to a house of correction per annum.16 For the system to work, however, there needed to be space in the prisons and houses of correction for vagrants to be held and punished prior to their removal. In the words of Richard Burn's justicing manual, once arrested and examined by a Justice of the Peace, vagrants should be 'publickly whipt by the constable. . . or . . . sent to the house of correction till the next session, or for any less time, as. . .[the] justice shall think proper'. Burn also allowed that vagrants could then be committed to up to six months further imprisonment on order of the Quarter Sessions and if deemed to be an 'incorrigible rogue' for up to two years. 17 For most of the 1780s, however, and in particular following the destruction of Newgate Prison in June 1780, the houses of correction in London and Middlesex that had been predominantly focused on punishing vagrants were either unavailable due to rebuilding work, or increasingly occupied by felony prisoners. At the same time, the criminal justice system, faced with unprecedented anxiety about public order and crime, increased the numbers of felons executed, whipped and sentenced to imprisonment, pressuring the system as a whole, and the provision for imprisoning minor offenders such as vagrants in particular. In these circumstances, the system for the punishment and removal of vagrants essentially broke down.

The nature of the problem can be seen in the sentencing patterns recorded in the Old Bailey Proceedings. While the number of convicted felons committed to either Newgate or the House of Correction seldom ran above single figures in the 1770s, a significant change is apparent from 1782, when sixty-four convicts received custodial sentences in these prisons. The number receiving this sentence reached a high point for the decade in 1786 when 133 men and women were convicted and sentenced to imprisonment.18 And it was not simply the numbers held in prison as punishment. The system was forced to accommodate a rising tide of criminals 
sentenced either to hang or to be whipped. Although imprisonment was not the main form of retribution in these cases, the condemned had to be held somewhere. The number of whippings carried out by the Sheriff of London rose from forty in 1779 to 164 in 1785 , while the numbers sentenced to be hanged at the Old Bailey rose from fifty-nine in 1779 to an all time high for eighteenth-century London of 158 in 1783 . Of course, many of these men and women were eventually pardoned and sentenced to a period of imprisonment or, after May 1787, transportation to Australia. Others were held for months prior to their eventual judicial murder. In either case, their presence substantially contributed to overcrowding in the prisons.19 The scale of the problem faced by the City and Middlesex can been seen in the number of offenders committed to New Prison. In the five months between May and September 1780, 678 prisoners were incarcerated.20 The precise number committed to the house of correction next door, the traditional repository for vagrants from Middlesex, is unknown, but in October 1789, one Justice of the Peace complained that 'a far greater number of persons is now in general imprisoned there than what the building is capable of containing with safety and convenience'.21 And in the following year, 1781-2, between 134 and 233 prisoners were being held in the Clerkenwell house of correction at any one time. To prevent escapes, a military guard was placed at both the prison and the house of correction.22 In December 1782, the sheriffs of London and Middlesex inspected these institutions and described the inmates as being in the:

Lowest state of misery and distress, without food to subsist upon, without fuel to warm them, without cloathing proper to keep them clean, or guard them against the inclemencies of the weather, the customary donations of the City and Sheriff being too inconsiderable to answer the purposes for which they were originally designed.23

A measure of the unhealthy conditions that resulted from this overcrowding can be found in the forty-six coroner's inquests performed on the bodies of prisoners who died while being held in these two prisons between 5th December 1780 and 9th April 1783.24 Newgate was fully reopened in 1784, relieving some pressure on New Prison and the House of Correction at Clerkenwell, but this did not solve the problem completely. For the most part the overcrowding was simply transferred. In November 1784, the keeper of Newgate recorded 529 inmates, comprising 362 felons and 167 debtors, of whom 300 lacked the rough rugs normally issued to each prisoner as a form of blanket.25 A year later the keeper recorded 680 prisoners. By October 1788 this figure had reached almost 750.26

At the same time, while the number of 'felons' tried for serious crimes increased in number, the 'character' of those sentenced as 'vagrants' appears to have changed and 211 men who previously would have been convicted of a felony were increasingly re-classified as vagrants. A straightforward, if problematic measure of this change can be observed in the gender composition of vagrants who were passed through Middlesex. Of the 108 adult vagrants passed through Middlesex between 4th December 1777 and 15th January 1778, seventy-one per cent, or seventy-seven, were women, and only twenty-nine per cent, or thirty-one, were men.27 By the same season six years later, in the winter of 1784, these percentages had almost reversed and among the adult vagrants passed between 8th January 1784 and 19th February, the figures stood at forty per cent women to sixty per cent men.28 It is likely that this change reflects the use of vagrancy legislation to punish men who in other circumstances might have been charged with 
felonies, but in any case, it reflects a significant shift in who was being classified as 'vagrant'. Rates of committal to the City's house of correction, Bridewell, and probably also to London's other houses of correction, likewise soared in the first few years of the 1780s, reflecting both a new intolerance of minor street disorder following the Gordon Riots and the old Palace's use as an alternative to Newgate while it was being rebuilt. Almost three thousand men and women were committed to Bridewell in 1783.29 Many were vagrants of one description or another, sentenced to suffer the usual punishment of a week or a month at hard labour and a whipping, but there were also felons, and people classified as vagrants who, in other years, would certainly have been tried as felons.

The incarceration of long-term prisoners, whether convicts sentenced to imprisonment or those awaiting the re-establishment of transportation, created particular problems. In 1781, reports from the House of Correction at Clerkenwell suggest that approximately sixty of the inmates had been convicted of a felony.30 By the winter of 1783, at least seventy-seven prisoners had been sentenced at the Old Bailey, again suggesting a felony conviction. A minority of these convicts had been held at Clerkenwell for over two years, since April 1781.31 The keeper of New Prison expressed his fears about the consequences in March 1781, referring to 'the capital convicts now in his custody who are very numerous and licentious and continually endeavouring to escape'. A week later a group of Justices of the Peace complained that the convicts who:

Continue there months and for years [are] in an idle and worse than an useless state corrupting each other and forming confederacies dangerous to the public. . . ever making disturbances and riots within the goale and encouraging others to misbehave. 32

Overcrowding inevitably meant that different types of prisoners were forced into the common areas of the prisons, ensuring that the attitudes and beliefs of more experienced and hardened prisoners spread to younger and more minor offenders. In the City of London, similar concerns were expressed about conditions in Bridewell, where the number of felony commitments increased dramatically following 1781 .

As a result of this overcrowding, the prisons and houses of correction became increasingly unmanageable. In November 1782, William Wood, a prisoner described as a 'vagrant' held at Clerkenwell house of correction, directly next door to the New Prison, put a pistol to the head of Thomas Mumford the chief servant to William Crosier, the keeper, and threatened to blow his head off if he did not deliver the keys. John Fitzgerald, also described as a vagrant, his legs still in irons, threatened to cut the throat of John Brown, also one of Crosier's servants, if he did not hand over the keys, and cooperate in their plan. In total, thirty-one people, all described explicitly as 'vagrants' escaped that night, of whom only twenty-one were ever recaptured.33 In response, new regulations were issued by the General Prison Committee in December 1782, restricting visitors and ordering a ready supply of cutlasses to be kept in the prison watch house. They also stipulated that 'a Rattle be Provided ... in Case of any Disturbance [an officer] may Alarm the Beadle at the Lodge that the Gate of the Hospital may be immediately Locked to Prevent Escapes'. 
Also in December 1782, Samuel Newport, the Keeper of New Prison, petitioned the Middlesex Bench, which in turn, petitioned the judges at the Old Bailey. The petition described the perilous mood of the inmates:

That since the late Dreadful Riots . . those confined in the . . Prison . . . have become most licentious and dissolute, are unruly and riotous to a very daring degree, continually committing the most outrageous acts, endeavouring to effect their escape, and encouraging others to join with them in their desperate designs. . . In such an attempt lately [made] three Prisoners [were] unfortunately killed and three more wounded.

Newport concluded his statement with a suggestion that the inmates were motivated by a 'determined Resolution ... . [for a] General Escape'.34 In an attempt to calm the situation a troop of soldiers was barracked in the gaol for over two years, at a cost of sixteen pounds per quarter. Their commander later explained their presence as a response to the 'riotous and dangerous state of the prisons'.35 As a counterbalance to this show of force, the prisoners' daily allowance of food was doubled, and poor prisoners were issued with shoes and clothes for the first time.36 In other words, the first half of the 1780s represent a moment in which the system for holding prisoners in the capital was in meltdown, with men who would otherwise have been transported, sentenced as vagrants, and then held for long periods in close proximity with a growing population of defendants convicted of serious crime.

No clear evidence of a direct and self-conscious change of policy towards imprisonment or the punishment of vagrants can be found in the archives, but by 1784 the overcrowding 3 in both Bridewell and the House of Correction at Clerkenwell seems to have precipitated a fundamental alteration in the treatment of vagrants. In that year, the number committed to Bridewell fell from over 3000 in the preceding year, to 612. But while the numbers imprisoned and recorded in the records of Bridewell fell dramatically, those listed as being passed from the City of London to the County of Middlesex for removal by the vagrant contractor actually increased, reaching 2,231 men and women in the year following October 1784. While the City continued to arrest and deport vagrants, it appears to have given up on its legal obligation to punish them.

Despite this new reluctance to punish vagrants, the City of London remained committed to policing vagrancy. In the following year, the City of London created a city-wide night 'patrole' for the specific purpose of taking up vagrants and loose, idle and disorderly men and women, quelling minor disturbances, and in the process, preventing serious crime. But, it is clear that, as Andrew Harris has argued, the City authorities had no wish to add to the pressures on the already overcrowded prisons.37

The single person most directly affected by this change in policy, apart from the vagrants themselves, was the 'vagrant contractor' for Middlesex, Henry Adams. Succeeding his father, James Sturgis Adams, Henry took over as the vagrant contractor for Middlesex in 1774. In that year, the number of vagrants transported from the houses of correction to the adjoining counties was approximately 1,200 per annum.38 With the change of approach implemented by the City in the mid-1780s, Henry Adams found himself confronted with an overwhelming tide of vagrants being passed from the City. Over 4,000 men, women and children were given into his 
hands in the full year after October 1784. Adams' paymaster was the Middlesex Sessions, and he complained bitterly to them, citing detailed evidence that demonstrated that the cause of his problems lay at the doors of the City of London. He also complained that the people being removed, 'do not appear to be Objects of the Vagrants Laws', many being 'dangerously Ill, some of which have died in his Hands'. Adams claimed that the growing number of vagrants passed from the City 'arose from the ease with which passes were obtained from the Magistrates of the City of London' and that 'the City Magistrates never . . . Cause the Vagrants to Be Whipp or Imprisoned . . . previous to their being passed'.39 This generated a furious letter to the Lord Mayor, who undertook to investigate what had caused this change, although there is no evidence that he followed up on this promise. To some extent, this increase in numbers could have resulted from the more aggressive regulation of street traders from 1784,40 and from the work of the newly created City patrol in 1785. But, more generally, it reflects a combination of a growing intolerance for the more disorderly inhabitants of London's streets and the increasing use of the label of 'vagrant' for serious offenders, with a simple recognition that the City simply did not have the prison facilities necessary to incarcerate them as the law stipulated. This change is important in itself, not only as evidence of changing attitudes, but more importantly, because for the poor this change in policy ensured that being arrested for vagrancy could provide an essentially painless route to accommodation and free transportation, and more unusually to medical care in hospital.

To be arrested for vagrancy required a certain wilfulness; and could be avoided with a humble demeanour and sharp eye to approaching authority. The growing numbers passed from the City suggest that for many marginal migrants and mendicants, avoiding arrest as a vagrant was becoming less urgent. It is also likely that many began to use removal as a 'vagrant' to subsidise seasonal transport costs. The cost of travel was particularly relevant for long distance, economic migrants, many of whom were Irish. In 1786, an extensive report on the cost of vagrant removal drawn up by a committee of the Quarter Sessions of Lancaster and Chester cited the removal of seasonal Irish labourers from Middlesex as 'vagrants' as a new grievance:

That many Irish vagrants which have been apprehended in the County of Middlesex. . . come to work in the harvest. . ., and there is reason to suppose that it is a common practice with them to collect all the money they have earned, and to intrust some one or more of their companions to carry over the wages of a great number of them, who being then without money, commit acts of vagrancy, by begging, etc. 41

In Henry Adams' returns for January 1785 approximately forty-five per cent of all vagrants were listed as being returned to Ireland. 42 
Rural History (2013) 24, 1, 53-66. c_ Cambridge University Press 201353

doi:10.1017/S0956793312000210

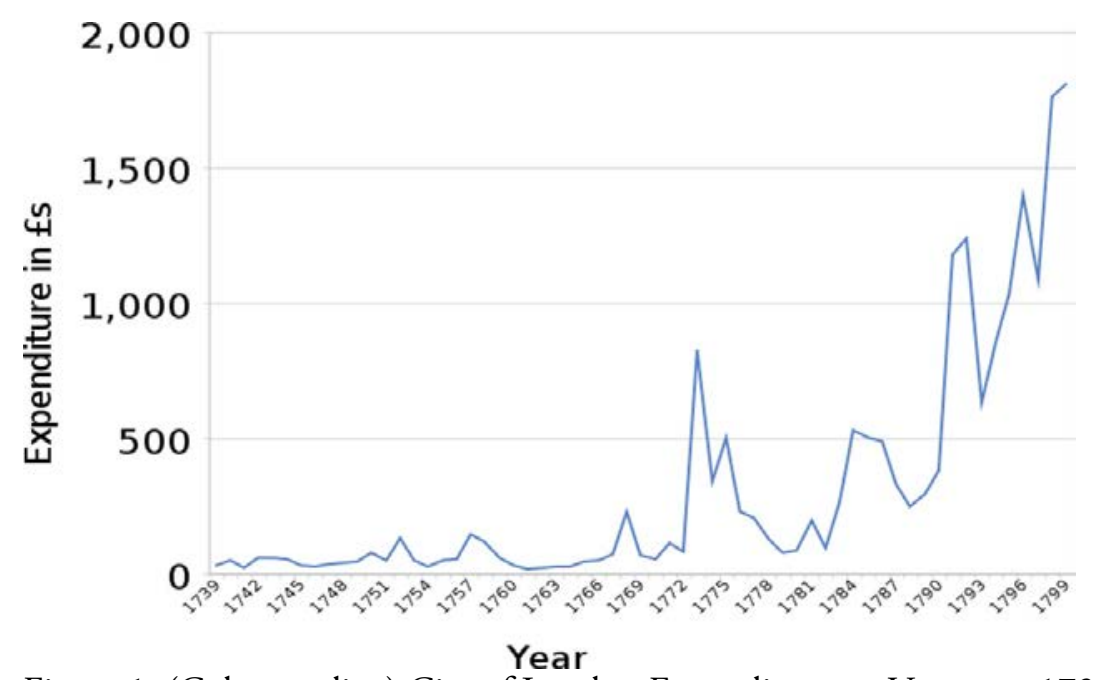

Figure 1. (Colour online) City of London Expenditure on Vagrants, 1739-99.

Source: London Metropolitan Archives, City Cash Accounts, MS 2/39-67.

If the accounts and petitions submitted by Henry Adams tell one story, it is largely repeated and extended in the massive City of London Cash Books, which record expenditure on vagrants examined and issued with a pass, or else imprisoned or maintained in hospital awaiting removal. These figures reflect the spike in removals complained of by Adams, but also evidence a continuing high level of expenditure through the middle of the 1780s. In 1786, a total of $£ 434$ was spent on the arrest, examination and processing of 2,209 vagrants, only gradually falling to 1,241 vagrants in 1787, and 1,3298 in 1788, before increasing dramatically in 1790 and 1791 (see Figure 1).43 The numbers of vagrants dealt with continued to be high and growing through the end of the century. In part, what one sees in these figures is a reflection of the shift in policy already discussed. The conveyance and removal of the growing numbers of vagrants in London and Middlesex, even in lieu of any corporal punishment, was increasingly, almost prohibitively, expensive. But the accounts also suggest that something else is going on, because although the numbers of vagrants arrested and removed essentially stabilised from the late 1780s, expenditure continued to be high and to continue to grow, even in the absence of much effort to imprison and punish. The explanation lies in part with a growing proportion of expenditure being used to support vagrants in hospital prior to removal.

On 24th November of 1782, Sarah Baylis was in the process of being removed from the City to Durham, where she had a settlement. She had been:

Extremely ill when . . . she had been lifted into the Cart into which she was to be conveyed with others. . . and . . . between Tyburn Turnpike and Bayswater she died in the Cart ... [T] he driver being informed of the circumstance, did neither stop or take the least notice thereof until he arrived at Acton when he applied to the Officer of the Parish for her Interment. 44 
This led directly to a coroners' inquest the next day, that in rather contradictory terms concluded she had died, 'in a natural way through weakness', as a result of 'the want of the common necessaries of life and of proper care being taken of her'.45 This in turn led to a detailed examination and report on Henry Adam's vagrant removal operation that focused on his provision of medical care for vagrants and on the deaths of Sarah Baylis and Jane Hill, who died in similar circumstances. The outcome included: a public reprimand in open court for Adams, in light of his, 'great inhumanity in his conduct in respect to Sarah Baylis'; the immediate discharge of the driver of the cart; 46 and an order that Adams:

Provide a Covered Cart with Benches and Straw safe and commodious for the conveying of Vagrants and that he provide proper places for the Reception of Vagrants at the Extreme parts of the County to which he conveys them and that on no account he presumes to remove any Vagrants who shall appear to be in such a state of Health that his or her Life may be in Danger by such Removal.47

In other words, by the early months of 1783 , not only were large numbers of vagrants being passed in to Adams' care without having been imprisoned or whipped, but Adams himself had been directed to refuse to remove anyone whose health and physical condition looked problematic. This created a further log-jam in the system, as Adams appears to have insisted that vagrants in questionable health be cared for by the City until they were sufficiently recovered to endure the process of removal. As a result, year by year, both the overall amounts spent on vagrants and the amount spent on caring for them in hospital prior to their removal, grew. And gradually, over the course of the second half of the 1780s, the City of London came to fund an increasingly comprehensive medical service for vagrants in hospital. By the 1790s, the cost of these referrals had risen to an average of $£ 756$ per year for vagrants clothed and supported in $\mathrm{St}$ Bartholomew's Hospital, and up to $£ 1057$ for those referred to St Thomas’s.48 Almost $£ 1800$ per year was being spent giving vagrants and beggars the best hospital care available.49 By the mid-1790s the magistrates were sending such 'great numbers of sick persons and infants utterly incapable of labour', for temporary respite in Bridewell, until space at St Thomas's was available, that the prison committee responsible for Bridewell was forced to approach the Lord Mayor and aldermen, and to ask that they: 'confer with the governors of the two hospitals as to the necessity of adopting some measures for receiving immediately all such patients as the magistrates may think proper to send'.50

To take a single year and a single hospital from a longer series and a more complex care environment, between March 1789 and April 1790, St Thomas's Hospital admitted 228 patients paid for by the City, the vast majority of whom were vagrants. This included 154 men and seventy-four women (in line with the gender balance found among vagrants), and seventy-two patients suffering from venereal disease. 51 In other words, the immediate crisis in the prisons of the mid 1780s was addressed through new building and the reopening of transportation, now to New South Wales, so that the crisis of vagrant removal became less pressing in the final years of the decade. But the reconfiguration of the vagrant system, both as an essentially non-carceral process, and as a route into the hospitals, was normalised. A combination of a series of tragic deaths, and their resulting scandals, with a continuing demand for arrest and removal, ensured 
that a crisis allowed a system supposedly ordered by legal precept to evolve in dialogue with the vagrants themselves.

Table 1

Vagrants Passed Through Middlesex, October 1782 to October 1785.52

\begin{tabular}{|c|c|c|c|c|c|}
\hline $\begin{array}{l}\text { Accounting } \\
\text { Period }\end{array}$ & $\begin{array}{l}\text { Tothill Fields } \\
\text { House of } \\
\text { Correction }\end{array}$ & $\begin{array}{l}\text { Clerkenwell } \\
\text { House of } \\
\text { Correction }\end{array}$ & $\begin{array}{l}\text { City of } \\
\text { London }\end{array}$ & $\begin{array}{l}\text { Other Parts of } \\
\text { England }\end{array}$ & Total \\
\hline $\begin{array}{l}\text { Oct. } 1782 \text { to } \\
\text { Oct. } 1783\end{array}$ & 428 & 708 & 754 & 1001 & 2891 \\
\hline $\begin{array}{l}\text { Oct. } 1783 \text { to } \\
\text { Oct. } 1784\end{array}$ & 577 & 756 & 1558 & 903 & 4107 \\
\hline $\begin{array}{l}\text { Oct. } 1784 \text { to } \\
\text { Oct. } 1785\end{array}$ & 512 & 760 & 2231 & 682 & 4185 \\
\hline $\begin{array}{l}\text { Oct. } 1782 \text { to } \\
\text { Oct. } 1785\end{array}$ & 1457 & 2224 & 4916 & 2586 & 11183 \\
\hline
\end{tabular}

The City never reinstated its policy of punishing vagrants. In 1790 a committee of Middlesex Justices of the Peace examined a group of three vagrants who had been passed from the City. In their report, they bitterly observed that the three had been 'advised to go to the Lord Mayor for passes which they did, and had them of course.'53 The vagrants whose lives were shaped by these developments remain largely mute and unknowable. But it is clear that men and women taken up in the system took advantage of the medical care and transport available. In the process they let a trickle of desperation, on their part and on that of the governors of the City and Middlesex, turn into a more substantial flow of medical attention and funding. The stentorian elite voices heard emanating from the Proclamation Society and from the individual projectors and pamphlet writers who published so much in the late 1780s and ' 90 s helped to reconfigure and rethink the system of policing, vagrant removal, and social welfare. But they were not simply acting in response to new ideas or a new sense of appropriate order. They were driven to action, as the City of London itself had been, by a system that had broken down following the Gordon Riots, which was barely able to contain a new prison population, and that had no traditional answer to the insistent vagrants who had found in the Lord Mayor and the City bench, a strangely accessible ear.

\section{Notes}

1. For the cart, see London Lives 1690-1800 (www.londonlives.org, consulted 2nd February 2012), Middlesex Sessions: General Orders of the Court (LMSMGO556070428); original currently held at the London Metropolitan Archives.

2. London Lives, City of Westminster Coroners: Coroners' Inquests into Suspicious Deaths, 'William Jenkins', 31st March 1784, (WACWIC65224IC652240200): Westminster Abbey Muniment Room. 
3. The history 432 of crime and the British system of criminal justice is extensive but for some authoritative recent accounts see, John Beattie, Crime and the Courts in England 1660-1800 (Princeton, NJ, 1986); John Beattie, Policing and Punishment in London, 1660-1750: Urban Crime and the Limits of Terror (Oxford, 2001); and Peter King, Crime and Law in England, 1750-1840: Remaking Justice from the Margin (Cambridge, 2006); Robert Shoemaker, The London Mob: Violence and Disorder in EighteenthCentury England (London, 2004). For the crisis of the 1780s see Tim Hitchcock, 'Re-Negotiating the Bloody Code: The Gordon Riots and the Transformation of Popular Attitudes to the Criminal Justice System', in Ian Heywood and John Seed, eds, The Gordon Riots: Politics, Culture and Insurrection in Late Eighteenth-Century Britain (Cambridge, 2012).

4. F. and J. Rivington, The Works and Correspondence of. . Edmund Burke (London, 1856), volume1, p. 305 .

5. Charles Cambell, The Intolerable Hulks: British Shipboard Confinement, 1776-1857 (Tucson, AZ, 3rd edn, 2001), and Simon Devereaux, 'The Making of the Penitentiary Act, 1775-1779', Historical Journal, 42 (1999), 405-33.

6. Old Bailey Proceedings (www.oldbaileyonline.org, ver. 6.0, 2nd February 2012), June 1780, trial of Thomas Haycock (t17800628-34). Thomas Haycock's role and background are substantially explored in Peter Linebaugh, London Hanged: Crime and Civil Society in the Eighteenth Century (London, 1991), pp. $346-7$.

7. Reports from the committees of the House of Commons (31st October 1776 to 6th June 1777),'Report from the Committee appointed to inspect and consider the Returns made by the Overseers of the Poor, in pursuance of Act of last Session:- Together with Abstracts of the said Returns', 15th May 1777 , p. 539.

8. Reports from the committees of the House of Commons (26th October 1775 to 23rd May 1776), 'Second Report', 21st May 1776, pp.289-96, for Middlesex, see p. 291. Surprisingly, the report does not record vagrant costs for the City of London.

9. Although there were some twenty-six Acts relating to vagrancy passed between 1700 and 1824, the two most significant pieces of legislation were 13 Ann. c.26, and 17 George II. c.5.

10. For the evolution of the laws of settlement see Lynn Hollen Lees, The Solidarities of Strangers: The English Poor Laws and the People, 1700-1948 (Cambridge, 1998); K. D. M. Snell, Parish and Belonging: Community, Identity and Welfare in England and Wales, 1700-1950 (Cambridge, 2006); J. S. Taylor, 'The Impact of Pauper Settlement 1691-1834', Past

and Present, 73 (1976), 42-74. For the role of King's Bench see Carolyn Steedman, 'Lord Mansfield's Women', Past and Present, 176 (2002), 105-43.

11. The best scholarship from a thin literature on vagrancy in this period includes Audrey Eccles 'The Adams' Father and Son, Vagrant Contractors to Middlesex 1754-94', Transactions of the London and Middlesex Archaeological Society, 57 (2006), 83-9; and Joanna Innes, 'Managing the Metropolis: London's Social Problems and their Control, c.1660-1830', in Peter Clark and Raymond Gillespie, eds, Two Capitals: London and Dublin 1500-1840 (Oxford, 2001), Proceedings of the British Academy, 107, pp. 53-79. Less satisfactory but occasionally useful is Nicholas Rogers, 'Policing the Poor in EighteenthCentury London: The Vagrancy Laws and their Administration', Histoire sociale/Social History, 24 (1991), 127-47.

12. Eccles, 'The Adams' Father and Son'. For details for each county, see Reports from the committees of the House of Commons (26th October 1775 to 23rd May 1776) 'Second Report', 21st May 1776, pp. 289-96.

13. For details of the arrangements in Middlesex see the 1757 contract between James Sturgis Adams and the county: London Lives, Middlesex Sessions: Sessions Papers - Justices' Working Documents July 1757 (LMSMPS504630003): London Metropolitan Archives, MJ/SP/1757/07. See also Reports from the committees of the House of Commons (26th

October 1775 to 23rd May 1776), 'Second Report', 21st May 1776, p. 291. 
14. The survival of an increasing number of 'pauper letters' from the 1780s reinforces the impression of eighteenth-century England as a society in which migration was commonplace The London Vagrancy Crisis of the 1780s 65 and 484 in which 'vagrancy' was poorly policed. For a comprehensive collection of one county's letters see Thomas Sokoll, ed., Essex Pauper Letters, 1731-1837 (Oxford, 2001), Records of Social and Economic History, ns, 30.

15. A Bill Intituled, An Act to amend and make more effectual the Laws relating to Rogues, Vagabonds, and other idle and disorderly Persons and to Houses of Correction (1744), 17 George II. c.5, pp. 2-3. This same list was then reproduced in every edition of the justicing manuals, found in every Justice of the Peace's study, up to and beyond the end of the century. See, for example, Richard Burn, The Justice of the Peace and Parish Officer (18th edn, London, 1797), volume 4, pp. 410-11.

16. Parliamentary Papers, 'Second Report. Reported by Thomas Gilbert, Esq. 21st May 1776', p. 291

17. Burn, Justice (1st edn, 1755), p. 494.

18. Old Bailey, Tabulating year against punishment subcategory, between 1770 and 1790 , counting by punishment.

19. Old Bailey, Tabulating year against punishment category, between 1770 and 1790, counting by punishment.

20. London Metropolitan Archives, 'Register of commitments to the New Prison Clerkenwell', July 1777 - October 1780, MJ/CC/V/002.

21. London Metropolitan Archives, 'Minutes of the Committee for repairing the House of Correction, Clerkenwell, and the New Prison, Clerkenwell, April 1773 - December 1781', MA/G/GEN/1 p. 40.

22. London Metropolitan Archives, 'Minutes of the Committee for repairing the House of Correction, Clerkenwell, and the New Prison, Clerkenwell, April 1773 - December 1781', MA/G/GEN/1 pp. 42, 67; 'Middlesex House of Correction, Clerkenwell', April 1781, MJ/CC/B/080; 'Signed report of John Sherwood, visiting Justice', 3rd July 1781. MA/G/GEN/010; 'Signed report of William Quarrill and John Staples, Visiting Justices, 2 August 1781',MA/G/GEN/013; 'Minute book of the Committee for building the House of Correction', MA/G/CBF/1 (27th January 1784).

23. London Metropolitan Archives, Repertories 187, p. 25 (3rd December 1782).

24. In October 1783 the coroner claimed a total of thirty five pounds and three pence for conducting the inquisitions, at fifteen shillings per inquisition: London Lives, Middlesex Sessions: General Orders of the Court, 5 October 1783, LMSMGO556070461): London Metropolitan Archives.

25. London Metropolitan Archives, 'Committee for Rebuilding the Poultry and Wood Street Compters', November 1784, CLA/032/02/006.

26. Simon Devereaux, 'Convicts and the State: The Administration of Criminal Justice in Great Britain during the Reign of George III' (unpublished doctoral thesis, University of Toronto, 1997), pp. 232, 254. 27. London Lives, Middlesex Sessions, Sessions Papers, 'A List of Vagrants, 4th. December 1777 to the 15th. January 1778' (LMSMPS506770118-22): London Metropolitan Archives. Children have been excluded from these calculations.

28. London Lives, Middlesex Sessions, Sessions Papers, 'A List of Vagrants, 8 Janr. to 19 Febr. 1784' (LMSMPS507780019-22): London Metropolitan Archives.

29. Faramerz Dabhoiwala, 'Summary Justice in Early Modern London', English Historical Review, 121: 492 (2006), Appendix (committals).

30. London Metropolitan Archives, MA/G/GEN/1, p.67, MA/G/GEN/10.

31. London Metropolitan Archives, 'Middlesex House of Correction, Clerkenwell', February 1781, $\mathrm{MJ} / \mathrm{CC} / \mathrm{B} / 81$.

32. London Metropolitan Archives, MA/G/GEN/1, pp. 56-7.

33. Old Bailey, William Wood, John Fitzgerald, December 1782, t17821204-71.

34. London Lives, Middlesex Sessions: Sessions Papers, September 1781, 'Petition of Samuel Newport' (LMSMPS507440060), London Metropolitan Archives, Ms. MJ/SO/1781/12. 
Rural History (2013) 24, 1, 53-66. c_ Cambridge University Press 201353 doi:10.1017/S0956793312000210

35. London Lives, Middlesex Sessions: General Orders of Court, September 1782 (LMSMGO556070380): London Metropolitan Archives, Ms. MJ/OC/10a.

36. London Lives, Middlesex Sessions: Sessions Papers, September 1781, 'An Account of Money Paid by James Crozier. . . for the poor convicts. . .' (LMSMPS507440064): London Metropolitan Archives, Ms. $\mathrm{MJ} / \mathrm{SP} / 1781 / 09$.

37. Andrew Harris, Policing the City: Crime and Legal Authority in London, 1780-1840 (Columbus OH, 2004), pp. 38-52.

38. Reports from the committees of the House of Commons (26th October 1775 to 23rd May 1776), 'Second Report', 21st May 1776, p. 291.

39. London Lives, Middlesex Sessions: Sessions Papers, April 1786 (LMSMPS508090268): London Metropolitan Archives.

40. London Lives, Middlesex Sessions: General Orders of the Court, April 1786 (LMSMGO556090233); Middlesex Sessions: Sessions Papers, April 1786 (LMSMPS508090268): London Metropolitan Archives.

41. Harris, Policing the City, pp. 45-6.

42. The Committee of the Magistrates of . . Chester and Lancaster . . for taking into Consideration the present Mode of Maintaining, Conveying, and Shipping Vagrants (1786), p.4. This report was sent to the Middlesex bench and a copy is available at London Lives, Middlesex Sessions: Sessions Papers - Justices' Working Documents (April 1786) (LMSMPS508090257):London Metropolitan Archives.

43. London Lives, Middlesex Sessions: Sessions Papers, 'A List of Vagrants Convey'd. . . 2d Decr. to 6th January 1785' (LMSMPS507920077): London Metropolitan Archives. This is not to suggest that this strategy was entirely new to the 1780 s.

44. London Metropolitan Archives, City Cash Accounts, 1784 - 1786, MS 2/58, fol.298. This fall could in part reflect the new availability of criminal transportation to New South Wales from May of 1787.

45. London Metropolitan Archives, Middlesex Sessions: General Orders of the Court, December 1782 (LMSMGO556070402): London Metropolitan Archives.

46. London Lives, Middlesex Coroners: Coroners' Inquests into Suspicious Deaths, $25^{\text {th }}$ November 1783, Sarah Baylis (LMCOIC651010155): London Metropolitan Archives. See also the note for her removal, and bill for her burial (shroud, bearers, fees, one pound, five shillings and sixpence): London Lives, Middlesex Sessions: Sessions Papers, December 1782

(LMSMPS507610096) and (LMSMPS507610100): London Metropolitan Archives.

47. London Lives, Middlesex Sessions: General Orders of Court, December 1792 (LMSMGO556070404): London Metropolitan Archives.

48. London Lives, Middlesex Sessions: General Orders of Court, February 1793 (LMSMGO556070428): London Metropolitan Archives.

49. From 1773 St Bartholomew's insisted that the City not only pay for medical care and washing, but also for clothing prisoners sent to the hospital. St Bartholomew's Hospital Archives, 'St Bartholomew's Governors' Minutes, 1770-86', Journal HA 1/14, p. 206.My thanks to Kevin Siena for this reference.

50. London Metropolitan Archives, 'City's Cash Accounts', 1791-99, MS 2/61, fos. 130-31, 294-95; MS 2/62, pp. 303-5, 358-61; MS 2/64, pp.353-56; MS 2/65, pp. 365-68; MS 2/66, pp. 344-47; MS 3/67, pp. 352-55; MS 3/68, pp. 263-66.

51. London Metropolitan Archives, Repertories 158, p. 116-17.

52. StThomas'sHospitalAdmissionsRegisterLondonMetropolitanArchivesH1/ST/B3/8, $26^{\text {th }}$ March 1789 to 22nd April 1790. My thanks to Kevin Siena for these figures.

53. London Lives, Middlesex Sessions: General Orders of the Court, January 1791 (LMSMGO556100109). 